\title{
Systemic Correlative Study between Systemic Lupus Erythematosus, Osteoporoses And Dehydroepiandrosterone-S(DHEA-S)level In Premenoposal Egyptian Women
}

\author{
*El Shafaey M. ,**Eman G.E. Helal, ***Abeer S.M. Gawish, \\ **Hala H. Elsayed \\ *Internal Medicine Department. Faculty of Medicine, Ain Shams University \\ **Zoology Department. Faculty of science Al Azhar, University. \\ ***Oral Medicine, Periodontology, Oral Diagnosis and Radiology Department, Faculty of \\ dentistry (girls) Al Azhar, University.
}

\begin{abstract}
Systemic Lupus Erythematosus (SLE) is an autoimmune disease commonly occurs in of childbearing age, with connective tissue inflammation particularly joints and causes characteristic rashes.

Subjects \& Methods: the present study includs30 premenopausal females, they were divided into 3 groups. Group I consists o ten premenopausal females without SLE, Group II include ten premenopausal females had SLE, disease duration less than three years, Group III include ten premenopausal females had SLE,disease duration more than three years. Bone mineral density (BMD) in the heel of right foot by Achilles Express in all groups had been performed. Estimation of the serum level of Dehydroepiandrosterone Sulphate (DHEA-S) hormone and serum level of calcium, phosphorous ,sodium and potassium.

Results: the results of the present study showed that in group II the BMD was $10 \%$ with osteoporotic , 40\% with osteopenic and 50\% with normal BMD, group III the BMD was $10 \%$ with osteoporotic, $60 \%$ with osteopenic and $30 \%$ with normal BMD. The correlations were done between BMD and serum minerals calcium, phosphorous, sodium and potassium in SLE patients ( Group II\&III). Statistically high significant increase was found among osteopenic versus control women. Moreover a significant increase of serum calcium and sodium while there was a significant decrease in serum DHEA-S, phosphorous and potassium.

Conclusions: There is a relationship between level of DHEA and the progression of SLE. Moreover there is relation between the decline in serum levels of DHEA-S and phosphorous, and the elevation of serum levels of calcium and the occurrence of osteoporosis in SLE.
\end{abstract}

Treatment with DHE is beneficial in controlling of the disease activity in LES patients.

\section{Introduction}

Systemic lupus Erythematosus (SLE) is the prototypical autoimmune disease characterized by the production of numerous autoantibodies (Arkrachaisiri \& lehman, 1999)

The particular etiology of SLE is unknown, but immunocomplexes autoantibodies , genetic ,environmental and endocrinal factors may play significant roles (Rubin,1999). About 98\% pf SLE patients have positive antinuclear antibodies (ANA) test, which are circulating and playing a role in the damage of several organs involvement (Evans,1998).
Lupus Erythematosus has been classified into SLE, Discoid lupus Erythematosus (DEL), chronic cutaneous lupus erythematosus, neonatal lupus erythematosus and drug-induced LE (Rubin,1999).

SLE affect female who is 20 to 40 years of age, it is a disease with multiorgan involvement. According to the American Rheumatism Association the diagnosis of SEL requires to fulfillament of four of eleven criteria (Dieppe et $a l ., 1985)$ which are :Cutaneous malar rash, Discoid scaly rash, Alopecia ,Raynud's 
phenomenon, Skin ulcer,Photosensitivity, Oral ulcers , Serositis, Renal disorder, muscluoskletal , Cardiopulmonary , Immunologic disorders, Neurologic disorders. Clinical manifestations :It is characterized by immunocomplex deposition causes small vessel vasculitis, which leads to multiorgan involvement such as renal (Moscik \& Kippel 1996), Cardiac ,hematologic , mucocutaneous and central nervous distruction (Bluestein, 1992).

Moreover, inflammation of the serous membranes results in joint, peritoneal and pleuropericardial symptoms.

The oral lesions are in the form of nonspecific ulcerations, salivary gland disease, tempromandibular disorders, mucositis ,glossitis (Rhodus \& Johnson, 1990).

Osteoporosis is defined as parallel loss of both mineral and matrix that render residual quantities inadequate to withstand minor trauma without fracture. (Cooper and Hihie, 1994). It is classified into primary and secondary forms. (Leboff, 1997)

Several medications are prescribed in the management of SLE. The most common drug is systemic corticosteroids and antimalarial drugs such as chloroquine appear to be also effective.

One of the major drawbacks ofglucocorticoid therapy is bone loss which characterized by exceed rate of bone resorption, the rate of bone formation, this may be caused by supraphysiologic levels leading to reduce formation and increase resorption (Adler and Rosen, 1994).

Dehydroepiandosterone(DHEA) is most abundant steroid in the blood sream produced mainly by the zone reticularis of the adrenal gland s. It is a parahormone that produced another hormones.

Possible therapeutic applications of DHEA supplementation include the prevention and/or treatment of heart disease, diabetes, obesity, osteoporosis and arthritis (Barrett etal., 1986). Rogers et al (2000) found that woman with higher levels of DHEA had greater bone mass than those with lower DHEA levels.

Robinzon \& Cutulo( 1999) found that the level of DHEA was below normal level in those people with SLE and DHEA supplementation may be therapeutic.

The present study was carried out to assess the correlation of SEL, osteoporosis and Dehydroepiandosterone-S(DHEA-S) level in premenoposal Egyptian women

\section{Subjects and Method}

\section{Patients selection:}

The present study comprised thirty premenopausal females which selected from the outpatient clinic of internal medicine department of Ain Shams University hospital, their ages ranged from $18-45$ years.

They are classified into three groups:

Group I : ten premenoposal women free from any systemic disease (control group)

Group II: ten premenoposal women with SLE for less than three years

Group III: ten premenoposal women with SLE for more than three years

The diagnosis of SLE in group II\&III was done according to the revised criteria of American Collage of Rheumatology (ACR).

The abovementioned groups were subjected to the following:

1-Careful medical history

2-SLE disease index (SLEDAI):

SELDAI is a valid model of experienced physicians global assessment of disease activity in lupus.

It experts in the 24 "most important" description of disease activity (Bombardier et al., 1992)

3-Radiological investigation: Densitometry for heel.

-Bone mineral density measurement It was performed by Achilles Express. The machine used in the present study was using ultrasound source and the data were analyzed by special soft ware for analyzing the densities of examined part. The data received were automatically compared with age, sex, and normal reference population. It was compared with normal peak bone mass for same sex and race. Bone mass deficit is quantitated as $\mathrm{gm} / \mathrm{cm} 2$ or approximate standard deviation above or 
below age matched normal means (ZScore). It was also correlated to deviation from normal peak bone mass ( $\mathrm{T}$-Score).

The heel was examined and analyzed to get the absolute bone density in $\mathrm{gm} / \mathrm{cm} 2$ and the percentage of bone density relative to $\mathrm{Z}$ and $\mathrm{T}$ scores.

4-Measurement of Dehydroepiandosterone level (DHEA-S):

Serum DHEA-S has been determined by using ELISA Kit. ()

5-Estimation of serum calcium $(\mathrm{Ca}+2)$ and serum phosphorus $(\mathrm{P}+3)$ :

Serum $\mathrm{Ca}$ and serum phosphorus were detected according to Teitz method (1983)

6- Estimation of serum sodium $(\mathrm{Na}+)$ :
Serum sodium(Na+) was carried out according to Trinder(1951) method

7- Estimation of serum potassium ( $\mathrm{k}+$ ):

Serum potassium $(\mathrm{k}+)$ was carried out according to Henry,1974 method. Statistical analysis was performed using student t- test.

\section{Results}

Assessment of the disease activity:

Using SLEDAI, the disease was active in $30 \%$ of patients of group II (disease duration less than 3 years ) and the disease was inactive in $70 \%$ of patients of the same group. However in group III (disease duration more than 3 years ) the disease was active in $40 \%$ of patients, and inactive in $60 \%$ of patients of the same group.(Table 1)

Table (1 )show disease activity of SLE patients

\begin{tabular}{|c|c|c|}
\hline \multirow{2}{*}{ Group II } & Active & Disease activity \\
\cline { 2 - 3 } & $30 \%$ of patients & $70 \%$ of patients \\
\hline Activity score & $6-10$ & $0-3$ \\
\hline Group III & $40 \%$ of patients & $60 \%$ of patients \\
\hline Activity score & $6-18$ & $0-3$ \\
\hline
\end{tabular}

Achilles express results in SLE women (group II\&III) on one site (Heel of Right Foot):-

As regard the bone mineral density assessment by Achilles express for heel of right foot, it was found that: In group II, the bone mineral density (BMD) range from -3.3 to 0.7 (mean \pm SD $-0.99 \pm 0.41$ ). While in group III, the BMD ranged from -3.1 to 0.3

(Mean \pm SD $-1.21 \pm 0.28$ ). From the present results the pattern of bone has been affected in SLE patients table 2.

Table( 2).Show Achilles express results in SLE women (group II\&III) on one site (Heel of Right Foot):-

\begin{tabular}{|l|l|l|l|}
\hline \multicolumn{2}{|l|}{ Groups } & \multicolumn{2}{|}{ Mean \pm SD } \\
\hline \multirow{3}{*}{ Group II } & Meel of right foot & & \multirow{2}{*}{$0.99 \pm 0.41$} \\
\cline { 2 - 3 } & Maximum & -3.3 & \\
\hline GroupIII & Minimum & -3.1 & \multirow{2}{*}{$-1.21 \pm 0.28$} \\
\cline { 2 - 3 } & Maximum & 0.3 & \\
\hline
\end{tabular}


According to the BMD of the site of heel group II were classified into:

Non osteopenic group with low risk of osteoporosis with value ranged from 0.2 to 0.8 . This group included $50 \%$ of patients.

Osteopenic group with moderate risk of osteoporosis with value ranged from -2.0 to -1.4 . This group included $40 \%$ of patients.

Osteoportic group (osteoporosis) with value ranged from -3.4. It included $10 \%$ of patients.
According to the BMD of the site of heel group III were classified into:

1-Non osteopenic group with low risk of osteoporosis with value ranged from -0.9 to 0.3 . This group included $30 \%$ of patients.

2-Osteopenic group with moderate risk of osteoporosis with value ranged from -1.5 to -1.3 . This group included $60 \%$ of patients.

3-Osteoportic group (osteoporosis) with value ranged from -3.1 . It included $10 \%$ of patients.(table 3)

Table( 3) show the BMD affecting in the site of heel of SLE patients

\begin{tabular}{|l|c|c|c|}
\hline Groups & $\begin{array}{c}\text { \%of non osteopenic } \\
\text { patients }\end{array}$ & $\begin{array}{c}\text { \%of patients with } \\
\text { osteopenia }\end{array}$ & $\begin{array}{c}\text { \%of patients with } \\
\text { osteoporosis }\end{array}$ \\
\hline Heel of right foot & $50 \%$ & $40 \%$ & $10 \%$ \\
\hline Group II & $30 \%$ & $60 \%$ & $10 \%$ \\
\hline
\end{tabular}

Statistical analysis of bone mineral density assessment by Achilles express for heel of right foot reveals an insignificant change in SLE patients of group II as compare to control group (group I).However in group III there was a significant decrease $(\mathrm{P}<0.05)$ when compare to group I table $4 \&$ fig 1.

Table( 4) show statistical analysis of BMD of heel of right foot in control and SLE patients:

\begin{tabular}{|c|c|c|c|}
\hline Groups & $\begin{array}{c}\text { Group I } \\
\text { (control) }\end{array}$ & Group II & Group III \\
\hline Mean & -0.033 & -0.99 & -1.21 \\
\hline \pm SD & \pm 0.34 & \pm 0.41 & \pm 0.28 \\
\hline probabilitis & & N.S & $\mathrm{S}$ \\
& & & $\mathrm{P}<0.05$ \\
\hline
\end{tabular}

NS: Non significant

S: Significant

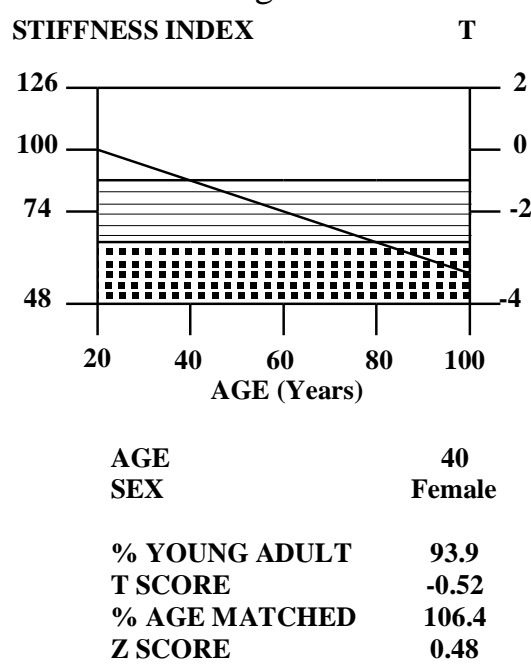


Non osteopenic of heel of right foot for some of control women (group 1)

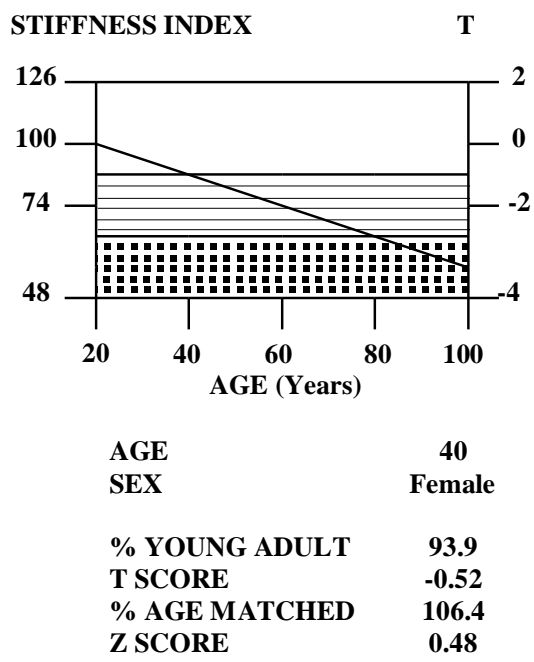

Non osteopenicof heel of right foot for SLE patients in group II( disease duration less than three years)

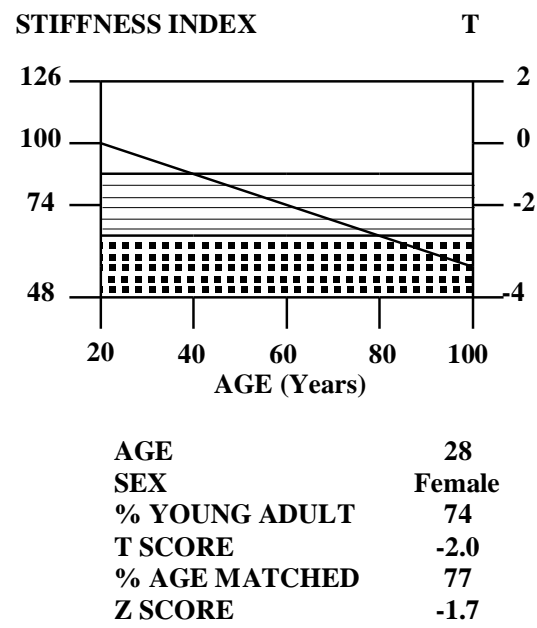

Osteopenia (Medium risk for osteoporosis) of heel of right foot for SLE patients in group II ( disease duration less than three years)

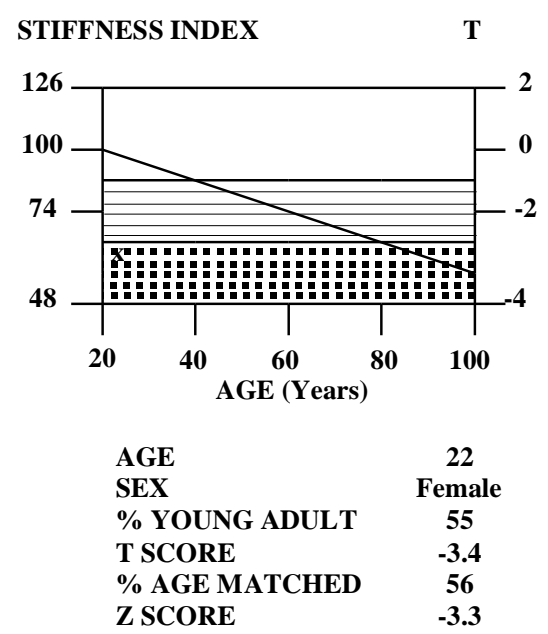


Osteoporosis of heel of right foot for SLE patients in group II( disease duration less than three years)

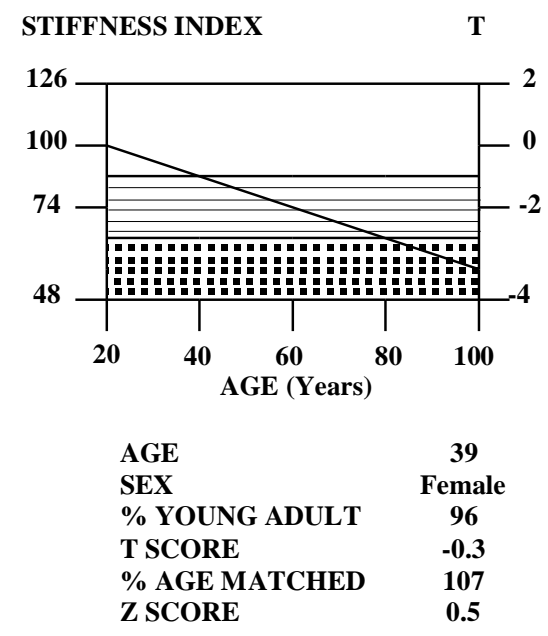

Non osteopenic of heel of right foot for SLE patients in group III ( disease duration more than three years

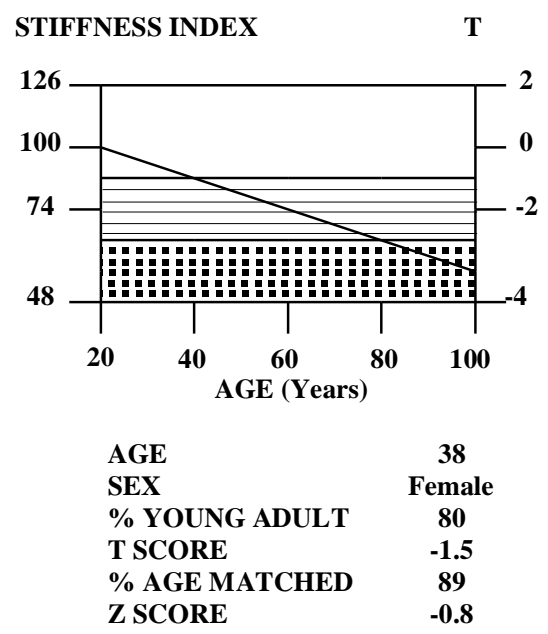

Osteopenia of heel of right foot for SLE patients in group III( disease duration more than three years)

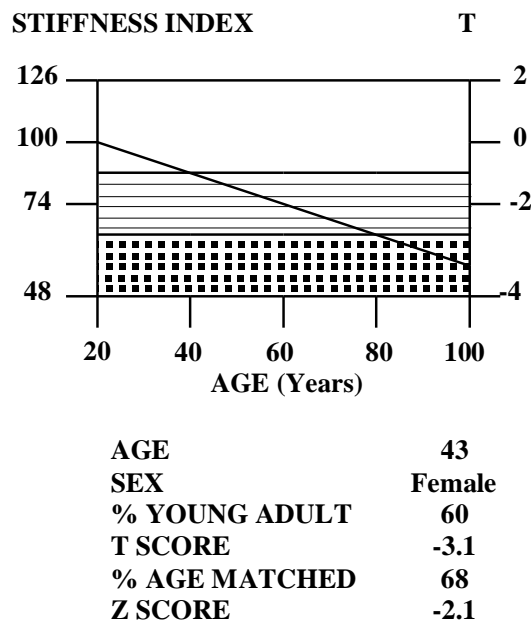


Osteoporosis of heel of right foot for SLE patients in group III (disease duration more than three years)

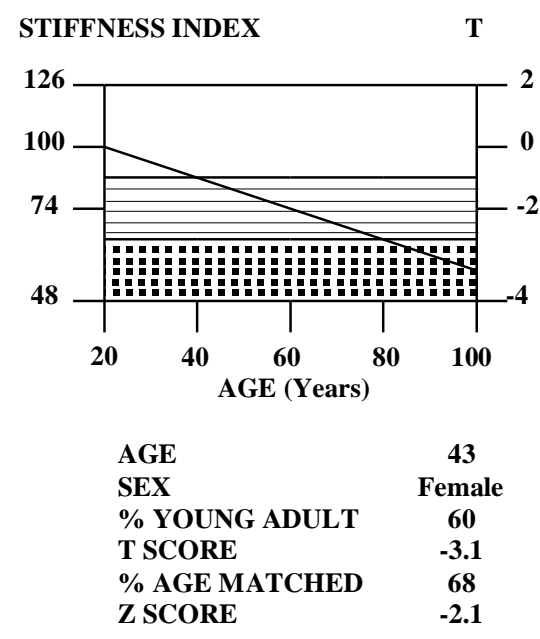

Hormonal analysis:

Serum DHEA-S level

The result showed notified decrease in serum DHEA-S level in SLE patients with osteoporosis, statistical analysis showed slightly significant decrease $(\mathrm{P}<$ $0.05)$ in SLE patients of both group II and group III ( table 5 \& fig 2 )

Table (5): Show the Serum DHEA-S level(mg/dl)in control \&SLE patients:

\begin{tabular}{|c|c|c|c|}
\hline Groups & $\begin{array}{c}\text { Group I } \\
\text { (control) }\end{array}$ & Group II & Group III \\
\hline Mean & 0.23 & 0.17 & 0.15 \\
\hline \pm SD & \pm 0.02 & \pm 0.015 & \pm 0.031 \\
\hline probabilitis & & $\begin{array}{c}\mathrm{S} \\
\mathrm{P}<0.05\end{array}$ & $\begin{array}{c}\mathrm{S} \\
\mathrm{P}<0.05\end{array}$ \\
\hline
\end{tabular}

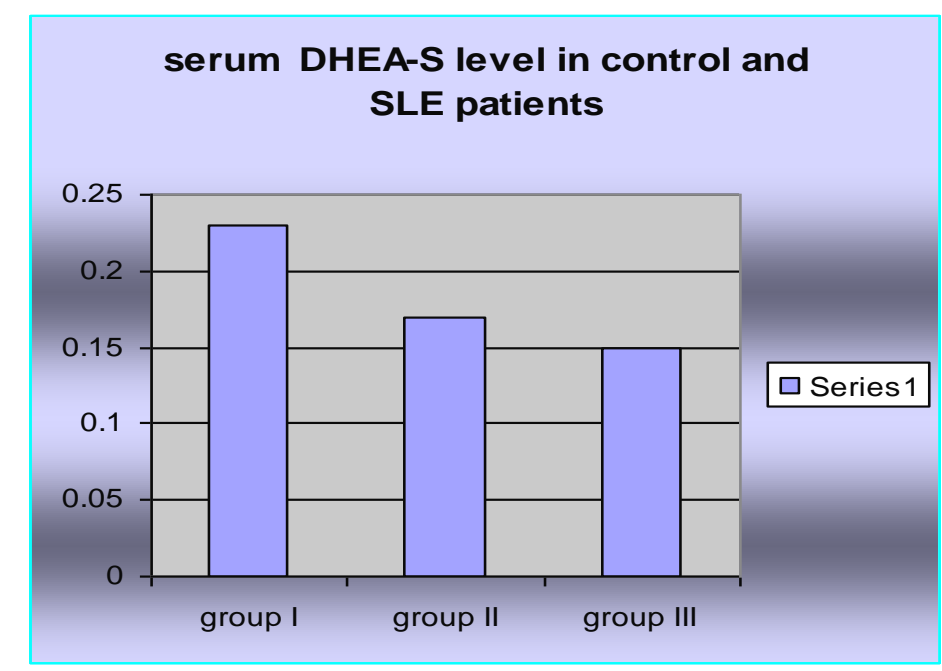

Fig (2) : Show serum DHEA-S levels in control and SLE patients 
Table( 6): Show different treatment modalities in SLE groups \&its effect on BMD

\begin{tabular}{|c|c|c|c|}
\hline $\begin{array}{c}\text { Group } \\
\text { treatment }\end{array}$ & $\begin{array}{c}\text { Noticeable effect } \\
\text { on BMD }\end{array}$ & Group II \\
\hline corticosteroids & Had osteopenia & $40 \%$ & $60 \%$ \\
\hline DHEA & $\begin{array}{c}\text { All values are normal with } \\
\text { decrease in disease activity in } \\
\text { group II treated with DHEA }\end{array}$ & $\begin{array}{c}10 \% \text { of patients are } \\
\text { treated with DHEA }\end{array}$ & $20 \%$ \\
\hline $\begin{array}{c}\text { Corticosteroids, osteal } \\
\text { calcium \&Antimalarial }\end{array}$ & BMD within normal & $50 \%$ & $10 \%$ \\
\hline Corticosteroids & Had osteoporosis & $10 \%$ & - \\
\hline
\end{tabular}

\section{Results of Minerals analysis:}

Serum calcium levels:

The result showed that serum calcium level of osteoporotic women had increased value, but non osteoporotic SLE women had normal value. Statistical to normal group (table $7 \&$ fig3.) analysis showed significant increase $(\mathrm{p}<$ 0.05 ) in group II (disease duration less than 3 years), but there is highly significant increase $(\mathrm{p}<0.01)$ in group III (disease duration more than 3 years ) when compared

Table (7): Show Serum calcium levels in the three groups

\begin{tabular}{|c|c|c|}
\hline Groups & Mean \pm SE & significance \\
\hline Group I & $9.3 \pm 0.73$ & \\
\hline Group II & $14.212 \pm 1.62$ & $\mathrm{P}<0.05$ \\
\hline Group III & $17.163 \pm 1.867$ & $\mathrm{P}<0.01$ \\
\hline
\end{tabular}

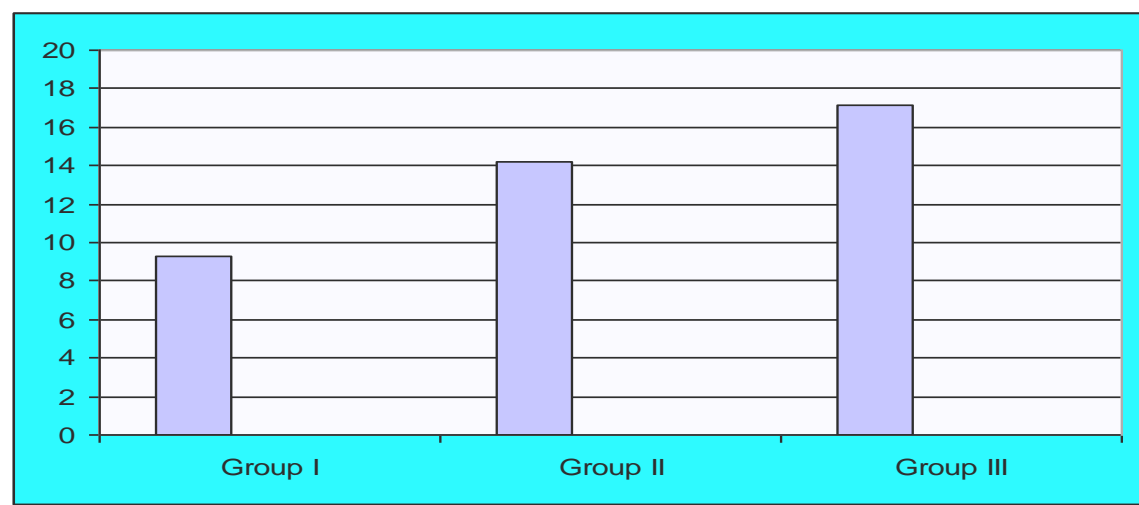

Fig 3 show Serum calcium levels in normal and SLE patients

Serum phosphorous levels:

Statistical analysis showed slightly significant decrease $(\mathrm{p}<0.05)$ in group II, but there was highly significant decrease $(\mathrm{P}<0.01)$ in group III as compare to normal group (table $8 \&$ fig 4 )

Table (8): Show serum phosphorous levels in normal and SLE patients

\begin{tabular}{|l|l|l|}
\hline Groups & Mean \pm SE & significance \\
\hline Group I & $3.49 \pm 0.395$ & \\
\hline Group II & $2.35 \pm 0.134$ & $\mathrm{P}<0.05$ \\
\hline GroupsIII & $1.87 \pm 0.0187$ & $\mathrm{P}<0.01$ \\
\hline
\end{tabular}




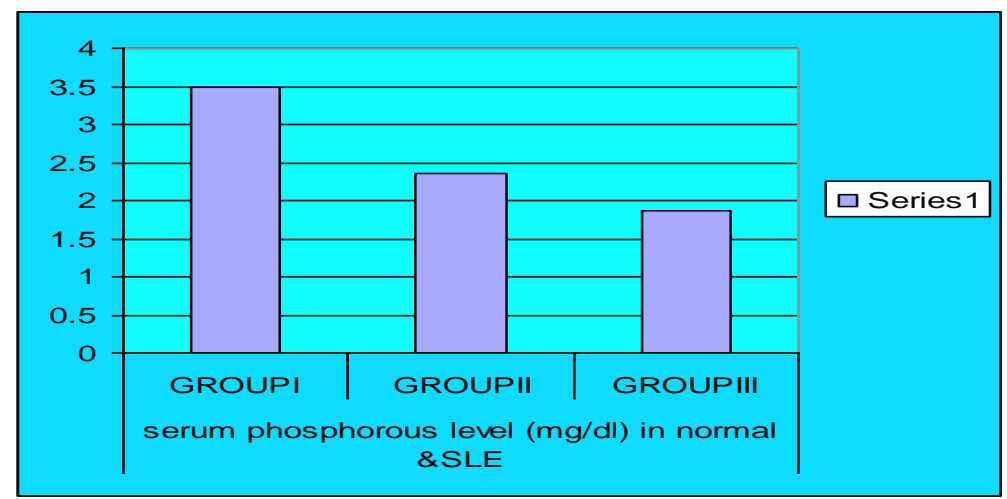

Fig( 4): Shows serum phosphorous levels in normal and SLE patients

Serum sodium level:

The result showed that serum sodium level was significantly increase $(\mathrm{p}<0.05)$ in both group II (disease duration less than
3 years ) and group III ( disease duration more than 3 years ) as compared to normal group (table 9, fig,4)

Table (9): Show serum sodium level (mmol/l) in normal and SLE patients

\begin{tabular}{|c|c|c|}
\hline Groups & Mean $\pm \mathrm{SE}$ & significance \\
\hline Group I & $138.51 \pm 1.26$ & \\
\hline Group II & $148.3 \pm 3.32$ & $\mathrm{P}<0.05$ \\
\hline GroupsIII & $147.48 \pm 3.41$ & $\mathrm{P}<0.05$ \\
\hline
\end{tabular}

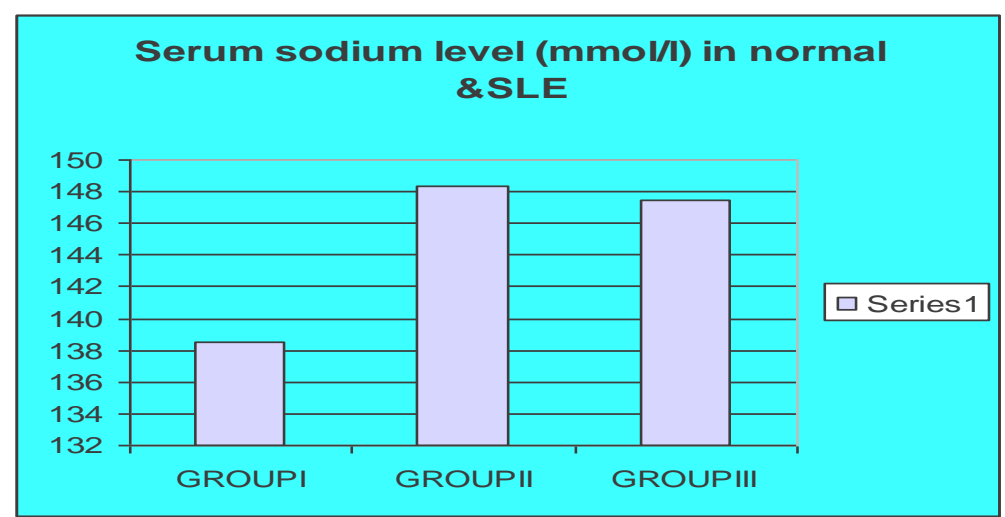

Fig (5) : Show serum sodium level in normal and SLE patients

\section{Serum potassium level:}

The result of the present study showed that serum potassium level was significantly decreased $(\mathrm{p}<0.05)$ in both group II (disease duration less than 3 years and group III ( disease duration more than
3 years ) as compared to normal group (table 10, fig,5)

Table 10 show serum potassium levels $(\mathrm{mmol} / \mathrm{l})$ in normal and SLE patients

Table (10): Shows serum potassium levels(mmol/l) in normal and SLE patients

\begin{tabular}{|l|l|l|}
\hline Groups & Mean \pm SE & significance \\
\hline Group I & $5.54 \pm 0.22$ & \\
\hline Group II & $4.06 \pm 0.32$ & $\mathrm{P}<0.05$ \\
\hline GroupsIII & $4.04 \pm 0.54$ & $\mathrm{P}<0.05$ \\
\hline
\end{tabular}




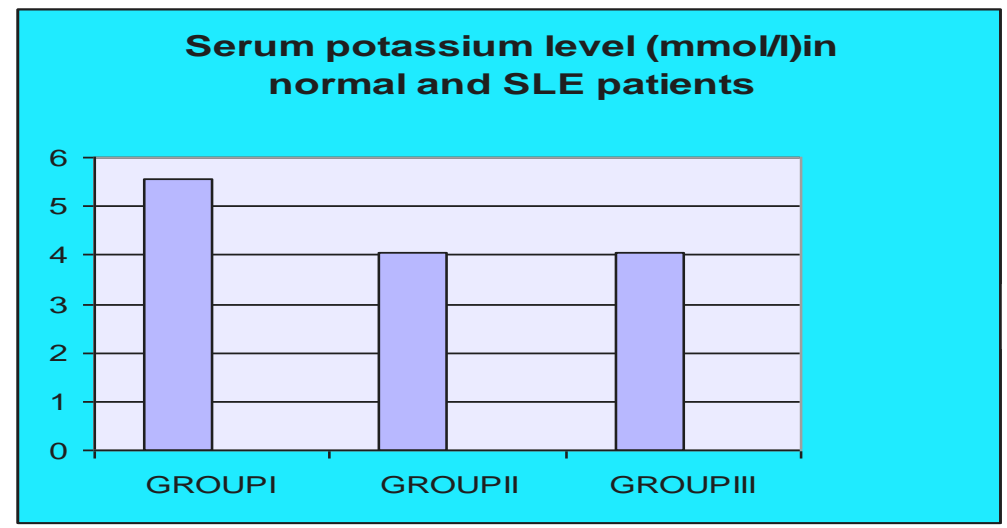

Fig. (5) : Shows serum potassium levels in normal and SLE patients

Comparison between non osteopenic and osteopenic groups II\& III (SLE patients) and group I( normal)

-Regarding to the serum calcium level (fig.7) there is a high significant increase among osteopenic Vs non osteopenic SIE patients, while there is a high significant decrease in serum phosphorous level (fig.8) in both osteopenic Vs non osteopenic SIE patients. -statistical analysis showed non significant difference between group I(normal) and group II\&III (non osteopenic SLE patients)

- However there was highly significant increase $(\mathrm{p}<0.01)$ in serum calcium and a highly significant decrease $(p<0.01)$ in serum phosphorus level between group I(normal) and groups II \&III osteopenic SLE patients (table 11 ,fig 6)

Table (11): Shows comparison between non osteopenic and osteopenic group II\& III (SLE patients) and group I( normal women)

\begin{tabular}{|c|c|c|c|c|c|c|}
\hline \multirow{2}{*}{ varibles } & $\begin{array}{c}\text { GroupI } \\
\text { (mean } \pm \text { SE) }\end{array}$ & \multicolumn{2}{|c|}{ Group II } & \multicolumn{2}{c|}{ Group III } & P vlue \\
\cline { 2 - 7 } & & $\begin{array}{c}\text { Non } \\
\text { osteopenic }\end{array}$ & osteopenic & Non osteopenic & osteopenic & \\
\hline Calcium (mg/dl) & $9.415 \pm 0.138$ & $10.345 \pm$ & $15.37 \pm$ & $10.896 \pm$ & $17.07 \pm$ & $P<0.01$ \\
& & 0.58 & 1.125 & 2.59 & 2.14 & \\
\hline Phosphorous & $3.665 \pm 0.225$ & $2.59 \pm 0.159$ & $1.31 \pm$ & $3.3 \pm 0.158$ & $1.67 \pm$ & P $<0.01$ \\
(mg/dl & & & 0.001 & & 0.121 & \\
\hline
\end{tabular}

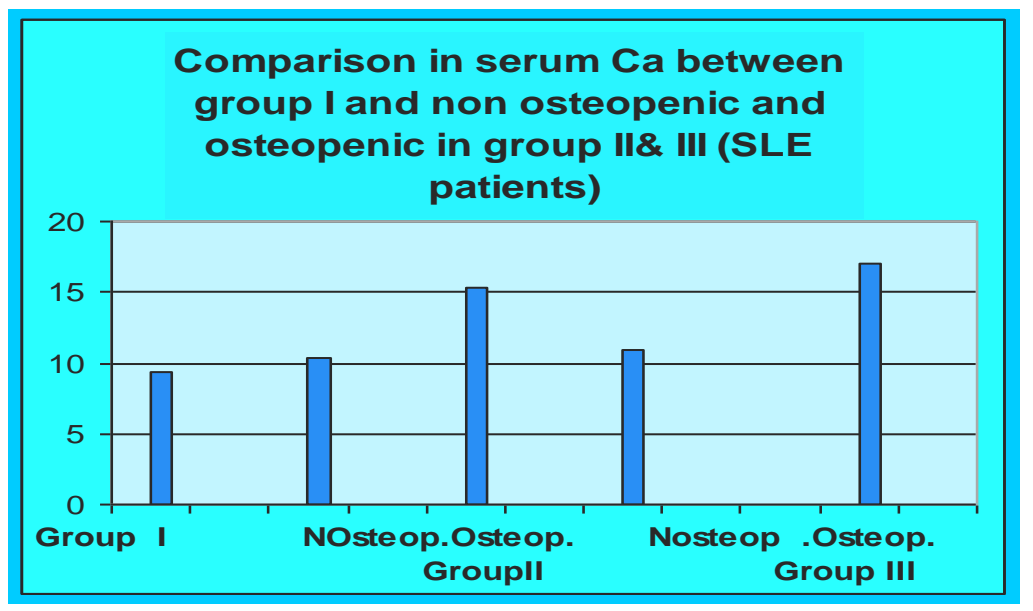

Fig (6) : Shows comparison between non osteopenic and osteopenic group II\& III (SLE patients) and group I( normal women) 


\section{Discussion}

The life expectancy of patients with systemic lupus erythematosus (SLE) has been improved (Reveille et al., 1990). This raises new concerns about the side effect of the drugs used in management of SLE which includes premature menopause , late malignancy, accelerated atherosclerosis, and osteoporosis. Several risk factors for osteoporosis are contributed in SLE patients such as; the inflammatory nature of the disease itself, disease related co-morbidity and its treatment. Bone loss is apparent early in the disease and this may be confounded primarily by corticosteroid treatment. (Devogelaer \& Nagant,1993).

Measurement of BMD should be considered in SLE patients who are at risk for osteoporosis , particularly those starting corticosteroid and in premenopausal women (Sen \& Keen, 2004).

In the present study, BMD in SLE patients of group II (disease duration less than 3 years) classified as $10 \%$ with osteoporosis, $40 \%$ with osteopenia and $50 \%$ with normal BMD, However in group III (disease duration more than 3 years) $10 \%$ with osteoporosis, $60 \%$ with osteopenia and $30 \%$ with normal BMD. This is in accordance with Formiga et al (1995), Ramsey et al. (1999), Teichmann et al. (1999) and Redlich et al. (2000) who noticed a high incidence of osteoporosis, in premenopausal women with SLE and this seems to be attributable, at least in part, to decreased bone formation.

Correlation between BMD and clinical parameters was calculated. It was found that BMD in SLE patients) was lower $(p<0.01)$ than in the control group. So according to WHO criteria $30 \%$ had normal BMD ,40\% had osteopenia and $30 \%$ had osteoporosis.

Lahita et al .(1987) and Dhullon et al (1990), suggested that the normal BMD in SLE patients may be due to increased rates of 16- $\alpha$ hydroxylation of estradiol in lupus patients with formation of oestrogenic metabolites such as 16- $\alpha$ hydroxyoestrone and oestriol, with possible protection of Lupus patients from osteoporosis. Another explanation for normal BMD could be related to their balanced diet with suitable amount of vitamin $\mathrm{c}$ which is necessary for sufficient protein matrix formation and intercellular substance secretions (Guyton and hall, 2000). Moreover, it may be due to treatment with osteal calcium, where in the present study $50 \%$ of SLE patients in group II and $20 \%$ of group III were treated with it. Significant lower BMDs were found in those not on calcium supplements in SLE patients, this result was in agreement with Lie et al .(1998).

Ten percent of SLE patients in the present study showed osteoporosis in both groups (II \&III). These patients were treated with corticsteroids only. Prolonged steroid therapy which known to increase the development of osteoporosis and fractures is the possible explanation as reported in other investigations (Lukert \& Raisz, 1990 and Sambrook et al., 1990). Disease duration is associated with an increased risk for osteoporosis, but the role of glucocorticoid treatment related variable exerting an influence on the development of osteoporosis. It also may be due to lack of estrogen secretion because estrogens have an osteoplast stimulating activity and/ or lack of physical stress on the bones because of inactivity of osteoplast (Guyton and Hall, 2000).On the other hand decreased vitamin D metabolism, decrease in weightbearing exercise, ovarian dysfunction related to medications or disease activity and direct effect of inflammation on bone turnover all of these are contributed to increase osteoporosis risk in SLE (Pettila et al.,2002).The present study showed significant decrease in the mean serum levels of DHEA-S in SLE patients especially osteoporotic and osteopenic women. Dehydroepiandosterone sulphate (DHEA-S) was the major adrenal hormone whose serum levels were significantly lower in SLE patients (Vogl et al., 2003). Straub et al. (1996) reported that, DHEA$S$ was lower in patients compared to controls. Moreover Formig etal (1997) found a significant positive relationship between DHEA-S and BMD in premen- 
opausal SLE women.Observational clinical studies and in vitro experiments have suggested that DHEA treatment might have a significant impact on immunological function and bone density (Merrill, 2003).

As regard serum minerals level the results of the present study revealed significant increase in serum calcium and significant decrease in serum phosphorous level among osteopenic SLE patients as compared with control women. This may be raised from mobilization of ca+ from bone, increased renal ca+ reabsorption by kidney. Moreover increase in formation of 1.25 dihyroxycholecalciferol, which increases ca+ absorption from the intestine and mobilizes the ions from the bones, however the plasma phosphorus level usually decreases as the plasma calcium level rise (Ganong, 2003).

In the present study the serum sodium level in SLE patients increased when compred to healthy patients. This may be due to a decrease in aldosterone secrtion, which leads to an increase in sodium reabsorption. The increased sodium reabsorption is also associated with increased water reabsorption and potassium secretion (Ganong 2003).

In the present study, $10 \%$ of SLE patients treated with DHEA, had normal BMD. This means that DHEA reduced the activity of disease. This is in agreement with Kurt et al. (2000), who reported that the treatment of osteoporosis with DHEA had possible beneficial effect upon BMD. Miklos (1995) reported a significant positive correlation between DHEA-S and BMD and stated that it is useful indicator for low bone mineral density in peri- and postmenopausal women. Van Vollenhoven et al. (1998) and Robinzon \& Cutulo (1999) stated that even if DHEA is not strong enough to control completely symptoms of SLE on its own, it might allow a reduction in dosage of the more harmful standard therapy. DHEA may be useful as a therapeutic agent for the treatment of mild to moderate SLE Ronald et al. (1995). Further studies of DHEA in the treatment of SLE are warranted

\section{Conclusion}

From the present study it is clear that there's a relationship between the BMD and the duration of the disease, relationship between level of DHEA and the progression of SLE and there is a decline in serum DHEA-S and the occurrence of osteoporosis in SLE patients.

\section{References}

1. Adler RA, Rosen CJ. 1994 Glucocor-ticoids and osteoporosis. Endocrinal. Metab. Clin. North. Am. 23:641-654.

2. Arkachaisri Tand Lehman, TJ. 1999 Systemic Lupus erythematosus and related disorders of childhood. Curr. Opin. Rheumatol. 11:83-87

3. Barrett -Conner E, Khow $\mathbf{K}$, Yen Sc. 1986 A prospective study of dehydroepian-dosterone sulphate , mortality and cardiovascular disease. New England J. of Med. 315:15191524.

4. Bevra HH. 1997Osteopenic bone disease. Arthritis and allied conditions. A textbook of rheumatology. Willium J koopman (ed), $13^{\text {th }}$ edition 22032231.

5. Black D, Cummings SR, Genant HK, Nevitt MC. 1992 Axial and appendicular bone density predict fracture in older women. J. BMR 7:633-638.

6. Bluestein HG. 1992The central nervous system in systemic lupus erythematosus.In: Systemic lupus erythematosus. New York: Churchill Livingstonep.639

7. Cassidy JT.1999 Systemic lupus erythematosus In: Textbook of pediatric rheumatology. $3^{\text {rd }}$ ed. WB Saunders, Philadelphia; 4:260-322

8. Colbert C, Mazess RB, Schmidt PB. 1970 Bone mineral determination in vitro by rediogaphic photodensitometry and direct photon absorpitometry. Invest. Radiol.5:336-340.

9. Cooper C, Aihie A. 1994 Osteoporosis : recent advances in 
pathogenesis and treat-ment. QJ. Med .87:203-209.

10. Devogelaer JP. and Nagant DED euxchaisnes C.1993 Therapy in the 1990. Osteoporosis. $\mathrm{Br} \mathrm{J}$ Rheumetol. 32 suppl 4:48-55

11. Dieppe PA, Docherty $\mathbf{M}$, Macfarlane DG, Maddison PJ. 1985 Rheumatological Medicine. Churchill Livingstone, Edinburgh. Concise British textbook.

12. Dhullon VB, Davies MC, Hall ML, Round JM, Ell PJ and Jacobs HS. 1990 Assessment of the effect of oral cortico-steroid on BMD in SLE. A preliminary study with DEXA. Ann. Rheum. Dis. 49:624-626.

13. Dykman TR, Gluck OS and Murphy WA. 1985 Evaluation of factors associated with glucocorticoid associated osteopenia in patients with rheumatic diseases. Arthritis Rheum. 28:361-368.

14. Evans J. 1998Antinuclear antibody testing in systemic autoimmune disease. Clin. Chest Med. 19:613-625.

15. Faulkner KG, Conn GEand Hasagawa BH. 1991 The effect of bone distribution on vertebral strength: assessment with patient specific non linear finite element analysis. Radiology 179:669-674.

16. Formig AF, Moga I, Nolla JM, Navarro MA, Bonnin $R$ and Roig- Escofet. 1997The association of dehydroepiandosterone sulphate levels with bone mineral density in systemic lupus erythematosus. Clin-ExpRheumatol.5(4):387-392.

17. Formig F, Moga I, Nolla JM, Pac M, Mitgadila $F$ and Roigescoft D. (1995) Loss of BMD in premenopausal women with SLE. Ann. Rheum. Dis. J. 54:274-276.

18. Ganong WF (2003) Hormonal control of calcium metabolism and the physiology of bone. Reiew of medical physiology. $21^{\text {st }}$ ed p.p 365-377.

19. Garn SM. (1970) The earlier gain and later loss of cortical bone. In :garm SM, ed. Nutritional perspective. Springfield, IL: Charles C Thomas.
20. Gluer CC, Steiger P, Salvdge R. (1990) Comparative assessment of dual-photon aborptiometry and dual energy radiography. Radiology 74:223-228.

21. Gyton AC, Hall JE. (2000) Parathyroid hormones, calcitonin, calcium and phosphate metabolism, vitamin $\mathrm{D}$, bone and teeth. Osteoporosis decreased bone matrix. Textbook of Medical physiology $10^{\text {th }} 899-928$.

22. Henary RJ.

Turbidimetetimeryic

(1974) determination of potassium. Cli Chem., New York, Sec Edit; 644 646.

23. Kurt R.,Sophie Z.,Hans P keener, Susanne $S$ and Stohlawetz.(2000) Bone minera density and biochemical parameters of bone metabolism in female patients with systemic lupus erythematosus. Ann Rheum. DIS. 59:308-310

24. Lahita RG, Bredlow HL, Ginzler. (1987) Low plasma androgens in women with systemic lupus erythematosus. Artritis Rheum.30:241-248.

25. Leboff M. (1997) disorders of bone and structural protein. In : Kelly W, Ruddy S, Harris E and Sledge C(eds). Textbook of Rheumatology p 1565. WB Sauders. Philadelphia.

26. Lie K, Taw LS, Young RP, KO GT, LIM, Lau EM. (1998) Loss o bone mineral density in Chinese premenopausal women with systemic lupus erythematosus treated with corticosteroids.Br. J. Rheumatol. 37(4):405-410.

27. Lukert BP, Raisz LG. (1990) Glucoco-rticoid- induced osteoprosis: Pathogenesis and management. Ann. Intern. Med.112:325-364.

28. Lukert BP, Rasiz LG. (1994) Glucoco-rticoids induced osteoporosis. Rheum. Dis. CLin. North. Am. 20:629-650.

29. Merrill JT. (2003) Dehydroepiandosterone , a sex steroid metabolite in development for systemic lupus erythematosus. Expert- Opin-Inverstig- Drugs 12(6):1017-1125.

30. Miklos S. (1995) Dehydroepiandosterone sulphate 
in the diagnosis of osteoporosis. Acta. Biomed. Ateneo. Parmense. 66 :139-46.

31. Mojciik CF, Klippel JH. (1998) End stage renal disease and systemic lupus erythe-matosus. J Am Dent Assoc 19:613-25

32. Pettila V, Leinonen P, Makkola A. (2002) Post portum bone mineral density in women treated for thromboprophylaxis with unfractionated heparin or LMW heparin. Thromb Haemost 87:182186.

33. Ramsey -Goldman R, Dunn JE, Cheng-Fang H. (1999) Frequency of fractures in women with systemic lupus erythematosus. Arthritis Rheum 42:882-890.

34. Redlich K, Ziegler S, Kiener HP, Spitzauer S, Stohlawetz P,Bernecker P. (2000) Bone mineral density and Biochemical parameters of bone metab-olism in female patients with systemic lupus erythematosus. Ann. Rheum. Dis. 59(4):308-310.

35. Reveille JD, Bartolucci A, Alarcon GS. (1990) Prognosis in systemic lupus erythe-matosus. Negative impact of increasing age at onset, black race and thrombocytopenia as well as cause of death. Arthitis Rheum. 33:3748.

36. Rhodus NL, Johnson DK. (1990) The pre-valence of oral manifestations of systemic lupus erythematosus. Quintessence Int.21: 461-465

37. Riggs BL, Wahner HW, Dunn WL. (1981) Differential changes in bone mineral density of the appendicular and axial skeleton with aging: relationship to spinal osteoporosis. J. Clin. Lnvest. 67:328-335.

38. Robinzon B, Cutulo M. (1999) Should dehydroepiandosterone replacement therapy be provided with glucocorticoids? Rheumatology (Oxford) 38:488495.

39. Rogers A, Hannon RA, Eastell R (2000) section of Medicine and University of Sheffield, UK. Biochemical markers as predictors of rates of bone loss after menopause. J. Bone miner. Res. 15(7):1398-1404.
40. Ronald F., Van Vollenhoven, Edgar G and James L.(1995) Dehydroepiand-osterone in systemic lupus erythematosus. American College of Rheumatology. 38: 1826- 1831

41. Rubin RL. (1999) Etiology and mechanisms of drug - induced lupus. Curr. Opin. Rheumatol. 11:357-363

42.Sambrook P, Birmingham J, Kempler S. (1990) Corticosteroid effects on proximal femur bone loss. J. Bone Miner. Res.5; 1211 1216.

43.Sen D, Keen R. (2004) Osteoporosis in systemic lupus erythematosus: prevention and treatment. Lupus 10:227-232.

44. Smith DM, Khairi MRA, Jhnston CC. (1975) the loss of bone mineral with aging and its relationship to risk of fracture. $\mathrm{J}$. Clin. Invest. 56:311-318.

45. Snchez R,Johnsson R, Ahlfors E. (1988) oral lesions of lupus erythematosus.patients in relation to other chronic inflammatory oral diseases: an immunologic study. Scand. Dent. Res. 96:569-578.

46. Spector TD, Hall GM, Mc CLoskey EV. (1993) Risk of vertebral fractures in women with rheumatoid arthritis. Br. Med. J.306:558-560.

47. Straub RH, Zeuner M, Antoniou E, Schulmerich J, Lan B. (1996) Dehydroepiandosterone sulphate is positively correlated with soluble IL 2 receptor and soluble intercellular adhesion molecule in systemic lupus erythematosus. J. Rheumatol. 23:5856-5861.

48. Teichmann j, lang U, Stracke H, Federlin K, Bertzel RG. (1999) Bone metabolism and bone mineral density of systemic lupus erythematosus at the time of diagnosis. Rheumatol. Int. 18(4): 137-140.

49. Teitz NW (1983) Calcium. In; Clinical guide to laboratory testes. Philadelphia, sounders.

50. Trinder $P$ (1951) Colorimetric determina-tion of serum sodium. Analyst, 6:596

51. Van Vollenhoven RF, Morabito LM, Engleman EG, McGuire JL. (1998) Treatment of systemic 
lupus erythematosus with dehydroepiandosterone: 50 patients treated up to 12 months. J. Rheumatol. 25: 285-289.

52. Vogl D, Falk W, Dorner M, Schlmerich J, Straub RH. (2003) Serum levels of progenolone and 17-hydroxy- progenolone in patients with rheumatoid arthritis and systemic lupus erythematosus: relation to other adrenal hormones. J. Rheumatol. 30(2):269-275.

53. WHO. (1994) Assessment of fracture risk and its application to screening for postmenopausal osteoporosis. Report of WHO study group. World Health Orga Tech. Rep.Ser1994; 843:1-129 quoted from: Kanis J, melton L, Christiansen C.1994: The diagnosis of osteoporosis. J. Bone Min. Res. 9:1137-1141.

\section{دراسة العلاقة بين الأنبة الحمراء و هشاشة العظام و مستوي هرمون

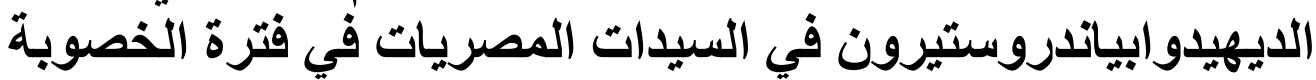

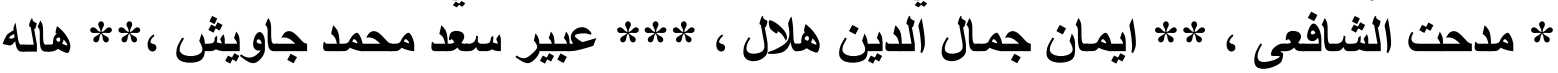

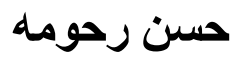

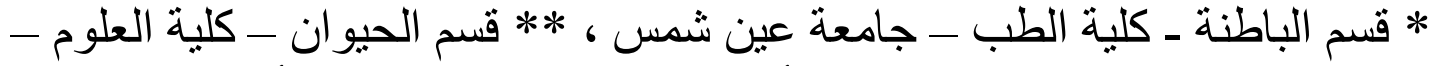

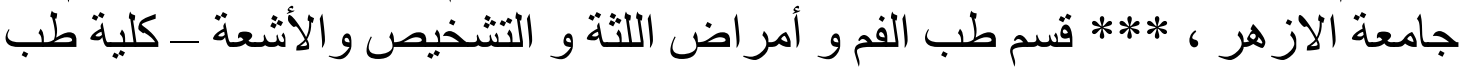
الأسنان - جامعة الاز هر الأنو

يعتبر مرض الذئبة الحمر اء مرض مناعي غير معروف السبب , يسب طفح جلدي

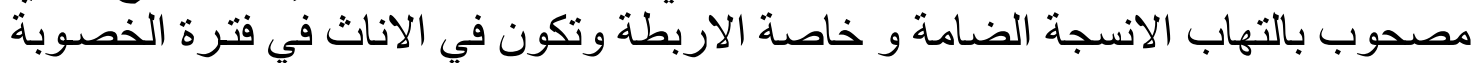

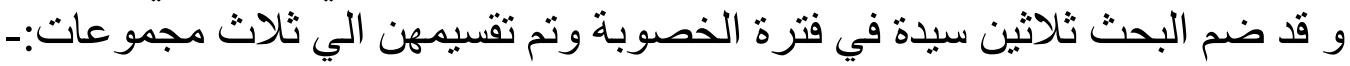

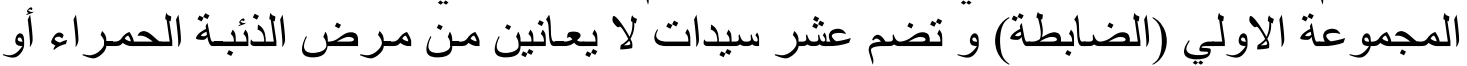
أي أمر اض أخرعة الأوبي المجموعة الثانية و تضم عشر سيدات يعانين من مرض الذئبة الحمر اء لمدة أقل من ثناث 
المجمو عة الثالثة و تضم عثر سيدات يعانين من مرض الذئبة الحمر اء لمدة أكثر من ثلاث سنوات

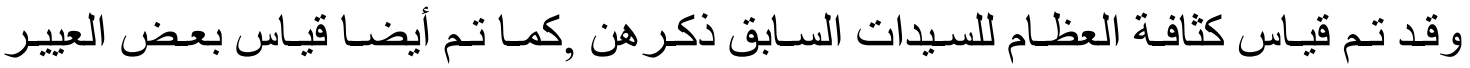

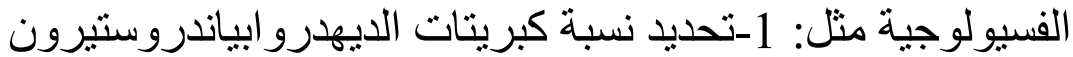

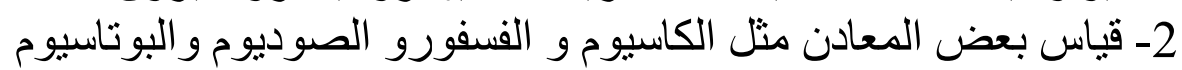

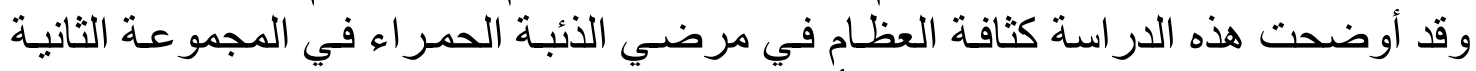

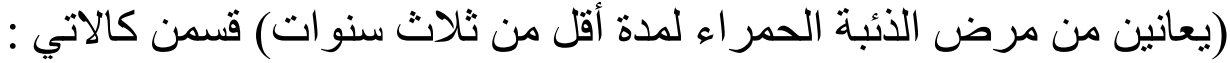

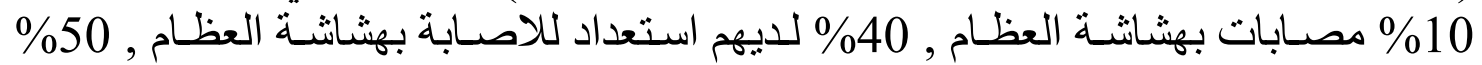

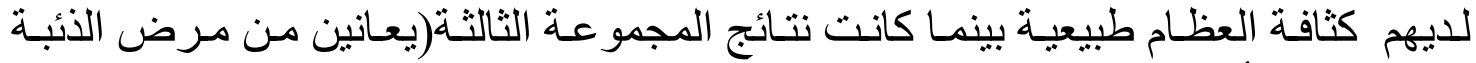

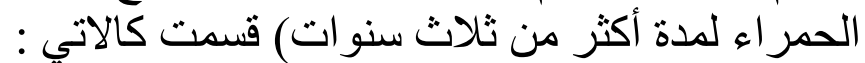

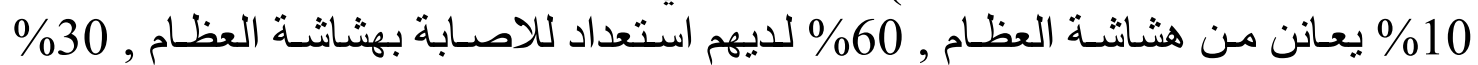
الباقين فكثافة العظام طبيعية.

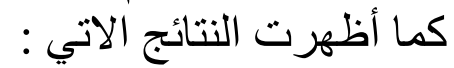

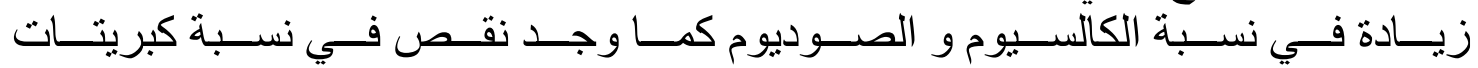
الديهيدرو ابياندروستيرون والنياء الفسفور و البو اتاسيوم

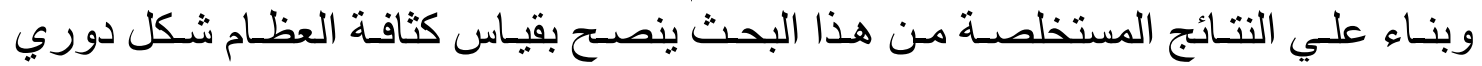

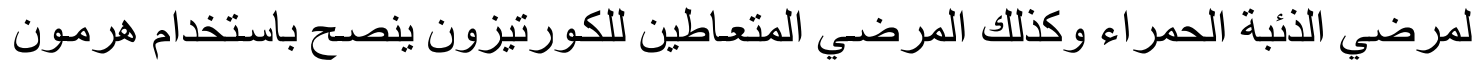

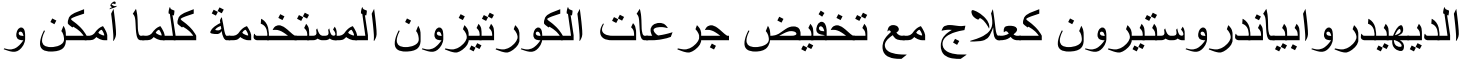

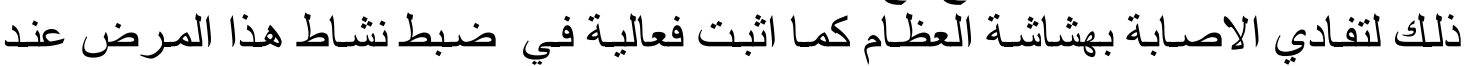

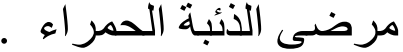

